\title{
Penentuan Anomali Gayaberat Regional dan Residual Menggunakan Filter Gaussian Daerah Mamuju, Sulawesi Barat
}

\author{
Determination of Regional and Residual Gravity Anomali Using Gaussian \\ Filtering in Mamuju Area, West Sulawesi
}

\author{
Adhika Junara Karunianto ${ }^{1 *}$, Dwi Haryanto ${ }^{1}$, Fajar Hikmatullah ${ }^{2}$, Agus Laesanpura $^{3}$ \\ ${ }^{1}$ Pusat Teknologi Bahan Galian Nuklir-BATAN, Jl. Lebak Bulus Raya No.9, Ps. Jumat, Jakarta, Indonesia, 12440 \\ ${ }^{2}$ Program Studi Fisika, UIN Syarif Hidayatullah, Jl. Ir. H. Djuanda No. 95, Tangerang Selatan, Indonesia, 15412 \\ ${ }^{3}$ Departemen Teknik Geofisika, ITB, Jl. Ganesha No. 10, Bandung, Indonesia, 40132 \\ *E-mail: adhika@batan.go.id
}

Naskah diterima: 24 November 2017, direvisi: 26 November 2017, disetujui: 30 November 2017

DOI: https://doi.org/10.17146/eksplorium.2017.38.2.3921

\begin{abstract}
ABSTRAK
Metode gayaberat merupakan metode geofisika yang sudah sering digunakan dalam prospeksi sumberdaya mineral. Parameter objek pencarian berdasarkan variasi pengukuran percepatan gayaberat di permukaan yang diakibatkan oleh variasi perubahan geologi bawah permukaan. Lokasi penelitian di daerah Mamuju Provinsi Sulawesi Barat yang secara tektonik merupakan wilayah geologi kompleks berada pada pertemuan tiga lempeng besar yaitu Pasifik, Indo-Australia, dan Eurasia serta Lempeng Filipina yang berukuran lebih kecil. Selain itu Mamuju merupakan wilayah dengan laju dosis radioaktivitas tinggi sehingga berpotensi memiliki sumberdaya mineral radioaktif. Tujuan dari penelitian adalah mendapatkan anomali gayaberat dengan cara melakukan pemisahan dan interpretasi secara kualitatif anomali gayaberat regional dan residual. Nilai Anomali Bouguer Lengkap (ABL) daerah penelitian yang didapat dari hasil pengukuran adalah 46,0 - 115,7 mgal. Berdasarkan peta ABL tersebut proses pemisahan anomali gayaberat regional dan residual dilakukan dengan menggunakan teknik Gaussian Filtering. Teknik filtering ini bekerja berdasarkan analisis spektrum perubahan amplitudo gayaberat secara spasial yang hasilnya berupa bilangan gelombang dengan cutoff sebesar $1,1736 \times 10^{-3} / \mathrm{m}$ dan panjang gelombang sebesar 5373,45 m. Anomali gayaberat regional dan residual berturut-turut memiliki rentang nilai 51,8 sampai $102 \mathrm{mGal}$ dan -10,4 sampai 14,8 mGal. Kedalaman wilayah spektrum masing-masing anomali tersebut dapat dihitung berdasarkan panjang gelombangnya yaitu anomali regional sebesar 970,97 $\mathrm{m}$ dan anomali residual sebesar 100,21 m. Terdapat lima zona berdasarkan peta anomali residualnya yaitu zona A, B, C, D, dan E. Anomali gayaberat positif paling besar terdapat pada zona A dan B yang diperkirakan dipengaruhi oleh keberadaan lava Adang dengan arah penyebaran relatif utara - selatan.
\end{abstract}

Kata kunci: gayaberat residual, gayaberat regional, anomali, Gaussian filtering, panjang gelombang

\section{ABSTRACT}

Gravity method is a geophysical method that has been frequently used in prospecting mineral resources. The parameter of searched object is based on variations of gravity acceleration measurements on the surface due to variations in sub-surface geological changes. Research area is located in Mamuju Area of West Sulawesi Province where tectonically a complex geological region, which is at a meeting of three large plates, the Pacific plate, the Indo-Australian plate and the Eurasian plate and the smaller Philippine plate. In addition, Mamuju is an area with a high radioactivity dose rate that has potency to radioactive minerals resources. The purpose of the research is to obtain gravity anomalies by using qualitative separation and interpretation of regional and residual gravity anomalies. Complete Bouguer Anomaly (CBA) value of the research area obtained from the measurements was 46.0 - $115.7 \mathrm{mGal}$. Based on the CBA map, the separation process of regional gravity anomalies and residual using Gaussian filtering technique conducted. This filtering technique works based on spectral analysis 
of gravity amplitude changes in spatial where the result is a cutoff wave number of $1.1736 \times 10^{-3} /$ meter and a wavelength of $5373.45 \mathrm{~m}$. The regional and residual gravity anomalies range from 51.8 to $102 \mathrm{mGal}$ and -10.4 to $14.8 \mathrm{mGal}$ respectively. The depth of influence of each anomaly is calculated based on their spectral wavelengths, resulting $970.97 \mathrm{~m}$ and $100.21 \mathrm{~m}$ for regional and residual anomalies respectively. There are five zones based on the residual anomaly map, which are zones $A, B, C, D$ and $E$. The heaviest positive gravity anomaly is found in zone $A$ and $B$, which is predicted to be influenced by Adang lava with relative north - south distribution.

Keywords: residual gravity, regional gravity, anomaly, Gaussian filtering, wavelength

\section{PENDAHULUAN}

Lokasi penelitian terletak di Kabupaten Mamuju, yang merupakan kabupaten baru pemekaran dari Provinsi Sulawesi Selatan pada tahun 2004 (Gambar 1). Struktur geologi daerah penelitian sangat komplek membentuk kesatuan geologi mozaik dengan litologi dan stratigrafi yang rumit, dikontrol oleh pertemuan tiga lempeng tektonik, diantaranya Lempeng Samudera Pasifik, Indo-Australia dan Filipina yang menunjam di bawah Lempeng Benua Eurasia [1]. Aktivitas tektonik subduksi menghasilkan beberapa gunung api di daerah Sulawesi, termasuk di Mamuju. Beberapa bentukan gunung api purba telah diidentifikasi menggunakan citra satelit [2]. Aktivitas magmatisme yang membentuk gunung api secara berulang menyebabkan terjadinya pengkayaan unsur mineral, salah satunya mineral radioaktif $[3,4]$.

Pengukuran sumber radiasi lingkungan oleh PTKMR-BATAN menunjukkan nilai laju dosis radiasi mencapai $2.800 \mathrm{nSv} / \mathrm{jam}$ di Mamuju [5]. Nilai laju dosis ini merupakan inidikasi keberadaan mineral radioaktif yang sumber radiasinya berasal dari alam [6]. Beberapa mineral radioaktif di dalam batuan telah diidentifikasi, diantaranya thorianite, davidite, gummite dan autunite [7]. Hal-hal tersebut membuat daerah ini menjadi sangat menarik untuk dipilih sebagai lokasi penelitian. Penelitian ini bertujuan untuk mendapatkan anomali gayaberat dengan cara melakukan pemisahan anomali gayaberat regional dan residual menggunakan metode filtering Gaussian dan identifikasi penyebaran serta hubungan rentang nilai daerah anomali gayaberat terhadap kondisi geologi permukaan.

Metode yang digunakan dalam penelitian ini adalah metode gayaberat. Metode gayaberat merupakan salah satu metode geofisika yang memanfaatkan disribusi parameter percepatan gayaberat di permukaan bumi. Banyak faktor yang mempengaruhi variasi percepatan gayaberat bumi seperti pasang surut, kondisi morfologi, udara bebas, bentuk bumi, densitas batuan dan seterusnya. Variasi densitas batuan bawah permukaan merupakan faktor yang sangat penting dalam rangka mendapatkan penyebaran anomali gayaberat untuk prospeksi geofisika.

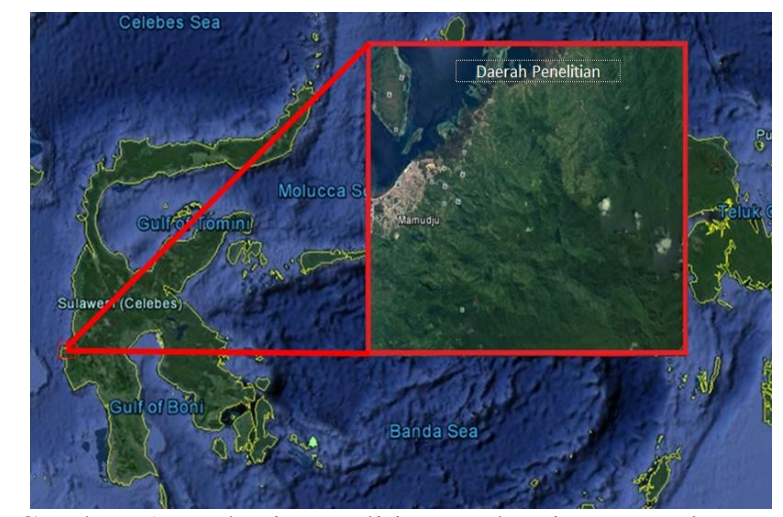

Gambar 1. Lokasi penelitian pada citra google map terletak di Mamuju Propinsi Sulawesi Barat (diperbesar pada garis warna merah).

Tahapan umum dalam melakukan studi gayaberat meliputi akusisi, pengolahan dan 
interpretasi. Pengambilan data lapangan telah dilakukan pada bulan Agustus sampai Oktober 2016 dengan cakupan luas area penelitian $20 \times 20 \mathrm{~km}^{2}$ dan jumlah stasiun pengukuran 50 titik dengan interval $2 \mathrm{~km}^{2}$ (Gambar 2). Tahapan pengolahan dan interpretasi adalah tahapan analisis data yang ditekankan dalam penelitian ini. Metode pengolahan menggunakan prinsip filtering Gausian yang sudah umum digunakan dalam pengolahan citra (image). Persamaan filtering ini merupakan persamaan linier yang digambarkan oleh perkalian matrik kernel Gauss.

Anomali Gayaberat Bouguer (ABL) merupakan peta anomali gayaberat yang sudah dilakukan berbagai proses reduksi sehingga variasi nilai anomali percepatan gayaberat yang dihasilkan hanya dipengaruhi oleh variasi rapat massa dari batuan di bawah permukaan. Nilai ABL ini adalah nilai total anomali yang ditimbulkan oleh pengaruh rapat massa batuan dari inti sampai permukaan bumi yang selanjutnya akan dipisahkan menjadi anomali regional dan residual. Interpretasi secara kualitatif dilakukan terhadap penyebaran daerah anomali residual di daerah penelitian yang dihubungkan dengan kondisi geologi dekat permukaan

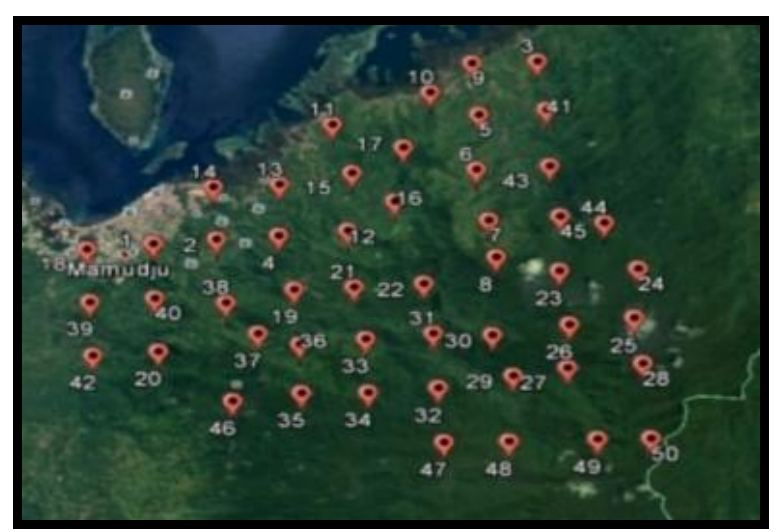

Gambar 2. Distribusi titik-titik pengukuran gayaberat di Daerah Mamuju.

\section{TEORI}

Metode gayaberat bekerja berdasarkan hukum Newton tentang gerak dan gaya tarik menarik antar dua benda dengan rapat massa tertentu yang dipisahkan oleh jarak keduanya. Kedua hukum tersebut direpresentasikan melalui persamaan percepatan gayaberat sebagai berikut:

$$
g=G \frac{M}{r^{2}}
$$

Nilai $G$ adalah konstanta gayaberat, $M$ adalah massa dari bumi, sedangkan $r$ adalah jarak suatu titik di permukaan terhadap pusat massa bumi. Metode gayaberat merupakan metode geofisika yang digunakan untuk mendapatkan distribusi nilai anomali percepatan gayaberat secara lateral di permukaan bumi yang mencerminkan kondisi geologi bawah permukaan.

Distribusi anomali percepatan gayaberat direpresentasikan berupa peta anomali gaya berat yang diistilahkan sebagai Anomali Bouguer Lengkap (ABL). Harga ABL merupakan gabungan dari anomali regional dan residual. Diperlukan suatu teknik pemisahan secara matematis untuk memisahkan dua anomali gayaberat tersebut sehingga terlihat jelas pembagian antara daerah regional dan lokal/residual.

Proses pemisahan anomali regional dengan residual dilakukan dalam domain frekuensi. Secara prinsip matematis, proses ini memungkinkan untuk melakukan pemisahan anomali ini karena objek-objek bawah permukaan akan memunculkan respon gayaberat secara spasial dengan frekuensi tinggi dan rendah. Karena respon gayaberat berada di domain jarak, maka memerlukan teknik konversi data dari domain jarak ke frekuensi. Teknik konversi ini menggunakan proses transformasi Fourier yang 
digambarkan secara sederhana melalui persamaan berikut ini [8]:

$$
F(k)=\int_{-\infty}^{\infty} f(x) e^{-i k x} d x
$$

Nilai $F(k)$ adalah fungsi spektrum dalam domain frekuensi dengan $k$ adalah bilangan gelombang, sedangkan $f(x)$ adalah fungsi spektrum dalam domain waktu dengan $x$ adalah jarak.

Untuk mendapatkan nilai $k$ yang sesuai perlu adanya proses analisis spektrum yaitu analisis harmonik yang digunakan untuk menganalisis fenomena osilator harmonik di alam dengan tujuan mendapatkan distribusi spektrum dari fenomena osilator dan menunjukkan karakteristik statistiknya [9]. Hasil dari analisis spektrum ini akan didapatkan nilai $k$ yang merupakan batas antara kawasan regional dan residual. Dengan menggunakan analisis spektrum kedalaman daerah pengaruh dari regional dan residual juga dapat dihitung. Nilai $k$ dan kedalaman ini yang akan digunakan sebagai input dalam proses filtering dalam pemisahan anomali regional dan residual.

Teknik filtering yang dilakukan dalam penelitian ini menggunakan metode Gaussian filter yang merupakan filter linier dengan memanfaatkan distribusi data dalam matriks kernel Gauss yang digambarkan secara sederhana melalui persamaan berikut [10]:

$$
G(i, j)=c \cdot e^{-\frac{(i-u)^{2}+(j-v)^{2}}{2 \sigma^{2}}}
$$

Nilai $G(i, j)$ adalah matriks kernel Gauss, $c$ adalah konstanta sedangkan $i, u, j$ dan $v$ adalah anggota di dalam matriks dan $\sigma$ adalah suatu konstanta nilai yang disesuaikan dengan ukuran matriks kernel Gauss. Selanjutnya matriks kernel tersebut dikonvolusikan terhadap matriks data yang sudah berada dalam kawasan frekuensi [11].

\section{METODOLOGI}

Tahapan pertama yang dilakukan dalam penelitian adalah studi pustaka yang dipersiapkan dalam rangka pembuatan kerangka kerja kegiatan di lapangan. Kerangka kerja bisa berupa peta kerja yang terdiri dari peta kontur, peta geologi, citra satelit dan lain-lain, yang harus dipersiapkan sebelum survei di lapangan.

Tahapan kedua adalah pengambilan data lapangan/akuisisi, yaitu pengukuran gayaberat dengan luas daerah 20x20 km² dan jumlah titik stasiun 50 buah. Tahapan ini dilakukan untuk menyiapkan Peta Anomali Bouguer Lengkap (ABL) sebagai data input untuk dilakukan pengolahan lebih lanjut. Nilai ABL merupakan parameter nilai anomali gayaberat yang diperoleh dari data pengukuran di lapangan setelah dilakukan berbagai reduksi. Nilai ABL ini merupakan respon anomali percepatan gayaberat di permukaan yang ditimbulkan oleh variasi perbedaan rapat massa batuan dibawah permukaan. Respon anomali ABL ini harus dipisahkan secara regional dan residual untuk memperjelas bentuk anomali dekat permukaan dan yang jauh dari permukaan bumi.

Tahapan ketiga merupakan tahapan pengolahan data yang ditekankan dalam penelitian ini, terdiri dari slicing/digitizing, transformasi Fourier, dan analisis spektrum. Analisis spektrum digunakan untuk membedakan sebaran nilai anomali ABL di dalam kawasan regional, residual/lokal dan noise. Slicing merupakan sampling data dari peta ABL yang akan ditransformasi Fourier. Hasil dari analisis spektrum adalah diagram scatter dari amplitudo dan bilangan 
gelombang yang didekati dengan fungsi linier. Perpotongan fungsi linier dari kawasan regional dan residual yang dipresentasikan nilai $k$ adalah acuan dalam melakukan pemisahan daerah anomali $[12,13]$.

Tahapan ketiga merupakan pengolahan data lanjut yang terdiri dari filtering dan interpretasi secara kualitatif. Filtering adalah teknik matematis yang digunakan dalam pemisahan anomali gayaberat regional dan residual. Dalam penelitian ini teknik filtering menggunakan fungsi Gaussian Filtering yang bekerja berdasarkan distribusi matriks kernel Gauss. Parameter input untuk proses filtering adalah panjang gelombang rata-rata dari sample data slicing. Interpretasi secara kualitatif dilakukan dalam menafsirkan jumlah dari anomali gayaberat residual yang dihubungkan dengan kondisi geologi di permukaan.

\section{HASIL DAN PEMBAHASAN}

Peta Anomali Bouguer Lengkap (ABL) daerah penelitian (Gambar 3) merupakan peta distribusi anomali gayaberat wilayah Mamuju dan sekitarnya dengan cakupan luas 20x20 $\mathrm{km}^{2}$. Jumlah stasiun pengukuran adalah 50 titik dengan interval antar stasiun pengukuran adalah sekitar $2 \mathrm{~km}^{2}$. Nilai anomali ini adalah nilai anomali gabungan dari anomali regional, residual, dan noise. Peta anomali residual diperlukan untuk melihat lebih detail sebaran perubahan nilai anomali gayaberat dari geometri geologi bawah permukaan sepanjang $2 \mathrm{~km}$. Peta ABL tersebut mempunyai rentang anomali berada pada kisaran 46,0 sampai $115,7 \mathrm{mGal}$ dengan pola sebaran anomali rendah cenderung berada pada arah utara (warna hijau - biru), sedangkan untuk anomali tinggi cenderung berada pada arah selatan (warna oranye merah) di daerah penelitian. Pada peta ABL terlihat warna merah muda berada di bagian tengah daerah penelitian merupakan daerah anomali gayaberat relatif paling tinggi yang memanjang berarah utara - selatan. Nilai daerah anomali ini sekitar 80 sampai 115 mGal.

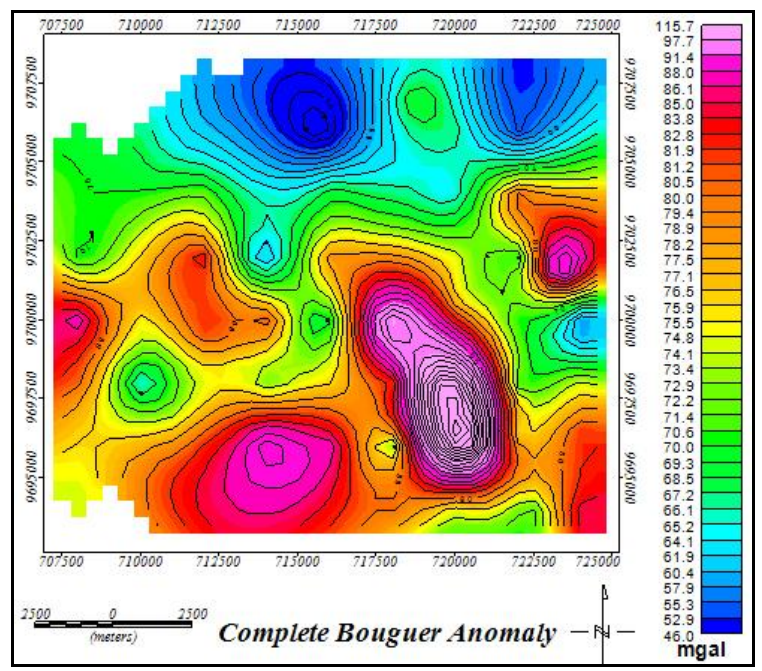

Gambar 3. Peta Anomali Bouguer Lengkap Daerah Mamuju dan sekitarnya

Terdapat enam slicing yang terdiri dari tiga line arah utara - selatan dan tiga line arah barat - timur (Gambar 4). Nama dari masingmasing line adalah line 1, 2, 3, 4, 5, dan 6 . Distribusi slicing data tersebut cukup mempresentasikan kondisi di daerah penelitian.

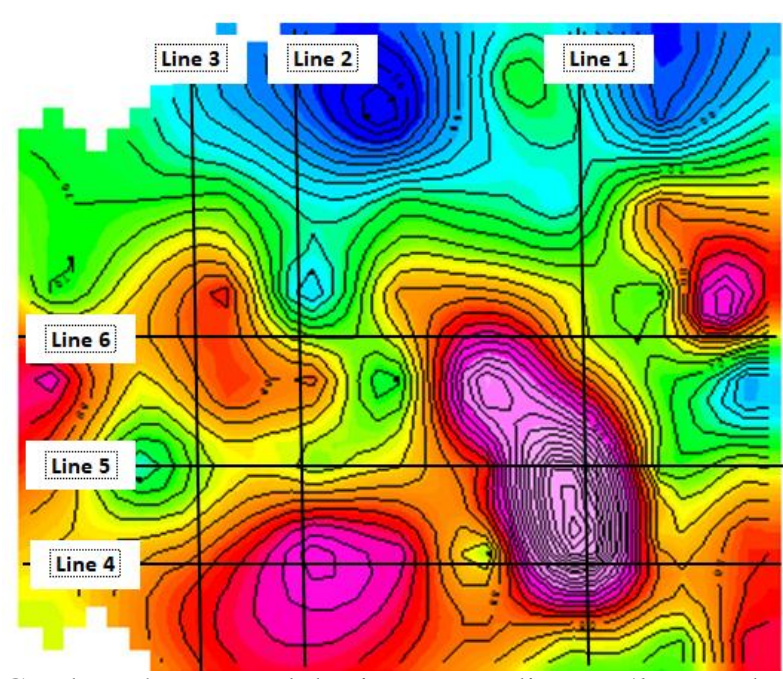

Gambar 4. Enam lokasi sayatan lintasan/line pada anomali gayaberat Bouguer. 
Transformasi Fourier mengubah suatu sinyal menjadi penjumlahan beberapa sinyal sinusoidal dengan berbagai frekuensi [14]. Analisis spektrum hasil transformasi Fourier dari masing-masing data slicing anomali gayaberat digambarkan berupa diagram scatter antara bilangan gelombang $(k)$ dan amplitudo (A). Nilai $k$ cutoff merupakan perpotongan fungsi linier regional dan residual yang digunakan untuk menentukan lebar jendela filter di dalam proses pemisahan nilai anomali gayaberat. Hubungan antara amplitudo $A$ dan bilangan gelombang $k$ adalah hubungan linier dengan gradien yang berbeda yang ditunjukkan persamaan garis lurus pada daerah spektrum regional (titiktitik warna biru), residual (titik-titik warna cokelat) serta noise (titik-titik warna abu-abu) (Gambar 5). Terdapat perpotongan garis pada batas daerah anomali regional-residual dan residual-noise yang akan menghasilkan bilangan gelombang cutoff ( $k$ cutoff). Hasil analisis spektrum yang diamati pada enam lintasan, yaitu line 1, line 2, dan line 3 pada arah utara - selatan, sedangkan line 4, line 5, dan line 6 pada arah barat - timur. Line 2 dan 3 terlihat memiliki gradien/slope yang relatif rendah dibanding lintasan lain. Hal ini kemungkinan besar dikontrol oleh arah anomali gayaberat yang positif.

Tabel 1 memperlihatkan kedalaman pengaruh respon anomali secara regional dan residual. Respon anomali pada tiap line di kawasan residual berada pada kedalaman yang hampir sama sekitar $100 \mathrm{~m}$ sedangkan di kawasan regional terdapat perbedaan dengan rentang dari 600 sampai $1.300 \mathrm{~m}$. Line 1, 4, dan 5 memiliki respon anomali gayaberat dengan kedalaman kawasan regional lebih dari $1 \mathrm{~km}$ sedangkan line 2, 3, dan 6 kurang dari $800 \mathrm{~m}$.
Tabel 1. Kedalaman anomali regional dan residual.

\begin{tabular}{ccc}
\hline \multirow{2}{*}{ Line } & \multicolumn{2}{c}{ Kedalaman } \\
\cline { 2 - 3 } & $\begin{array}{c}\text { Regional } \\
(\mathbf{m})\end{array}$ & $\begin{array}{c}\text { Residual } \\
(\mathbf{m})\end{array}$ \\
\hline 1 & 1163,32 & 96,37 \\
2 & 620,79 & 100,57 \\
3 & 696,11 & 100,21 \\
4 & 1223,01 & 96,66 \\
5 & 1354,17 & 102,59 \\
6 & 768,41 & 104,84 \\
\hline Rata-rata & $\mathbf{9 7 0 , 9 7}$ & $\mathbf{1 0 0 , 2 1}$ \\
\hline
\end{tabular}

Tabel 2 menunjukkan hasil analisis spektrum berupa nilai $k$ cutoff dan panjang gelombang $(\lambda)$ yang digunakan sebagai parameter acuan dalam proses pemisahan anomali regional dan residual. Nilai rata-rata $k$ cutoff adalah $1.1736 \times 10^{-3}$ digunakan untuk menghitung nilai panjang gelombang anomali gayaberat rata-rata di daerah penelitian yaitu sebesar $5373,45 \mathrm{~m}$.

Tabel 2. Panjang gelombang lintasan survei gayaberat.

\begin{tabular}{ccc}
\hline Line & $\begin{array}{c}\mathbf{k}_{\text {cutoff }} \\
(\mathbf{c y c l e} / \mathbf{m})\end{array}$ & $\begin{array}{c}\lambda \\
(\mathbf{m})\end{array}$ \\
\hline 1 & $1,0567 \times 10^{-3}$ & 5946,04 \\
2 & $1,2205 \times 10^{-3}$ & 5148,04 \\
3 & $1,2089 \times 10^{-3}$ & 5197,44 \\
4 & $1,2763 \times 10^{-3}$ & 4922,97 \\
5 & $1,1439 \times 10^{-3}$ & 5492,77 \\
6 & $1,1355 \times 10^{-3}$ & 5533,41 \\
\hline Rata-rata & $1,1736 \times 10^{-3}$ & 5373,45 \\
\hline
\end{tabular}

Peta anomali gayaberat regional (Gambar 6) memperlihatkan respon anomali regional di daerah penelitian dengan rentang nilai 51,8 sampai $102 \mathrm{mGal}$. Terlihat pada peta adanya gradasi pola sebaran anomali gayaberat dari tinggi ke rendah yaitu relatif dari selatan menuju ke utara. Sebaran anomali rendah pada peta ditunjukkan warna biru muda sampai tua dengan nilai kurang dari $70 \mathrm{mGal}$. Sebaran anomali sedang sampai tinggi pada peta ditunjukkan warna hijau sampai merah muda dengan nilai sekitar lebih dari 70 - 102 mGal. Peta anomali residual gayaberat 
(Gambar 7) memperlihatkan pola sebaran variasi respon anomali lateral yang kurang halus dibandingkan respon anomali regionalnya. Anomali tinggi ditunjukkan warna oranye - merah muda dengan rentang nilai sekitar 1 - 14,8 mGal. Anomali rendah ditunjukkan oleh warna hijau - biru dengan rentang nilai -10 sampai $1 \mathrm{mGal}$. Pola sebaran anomali rendah terlihat hampir selalu mengikuti pola sebaran anomali tinggi.

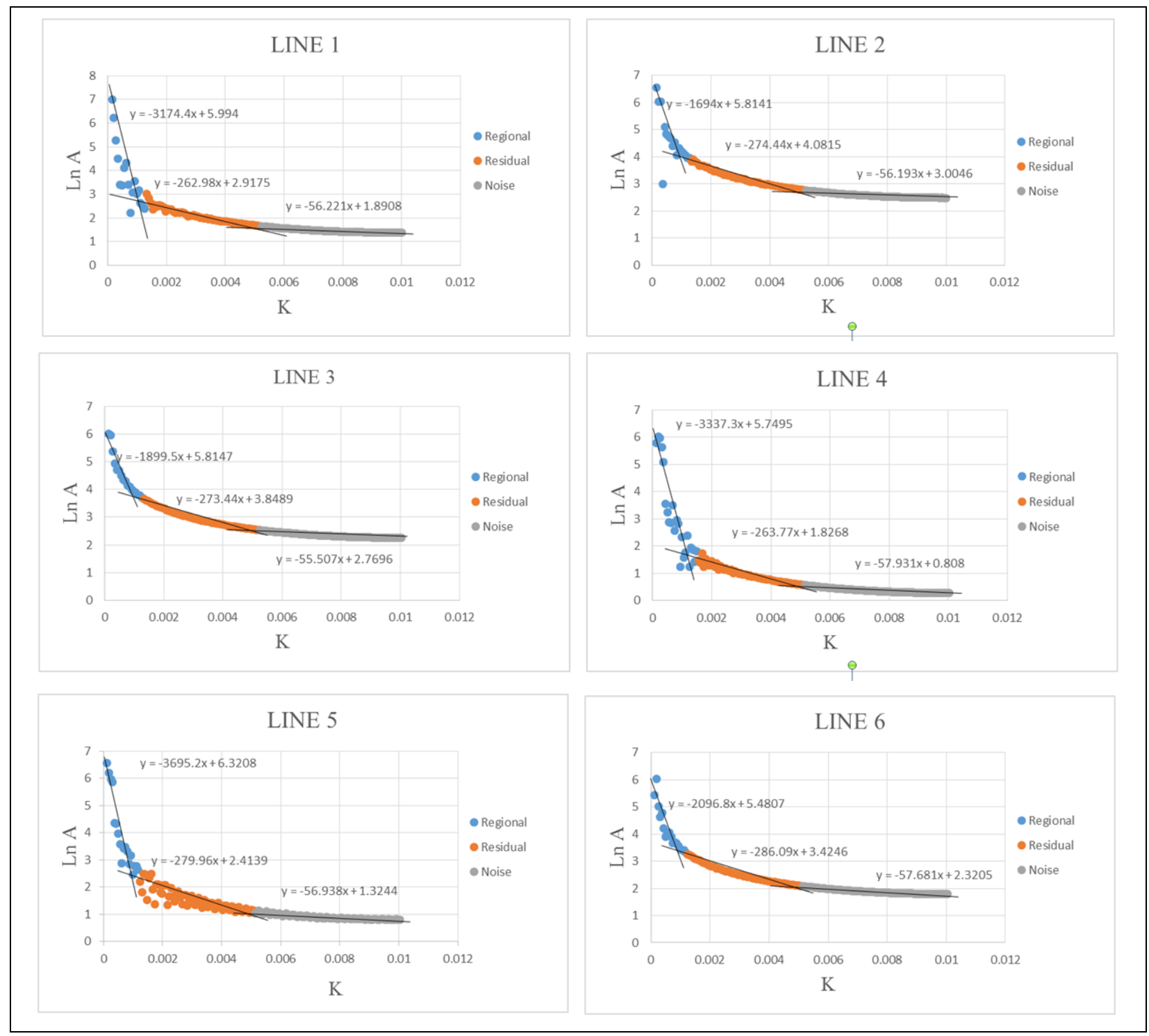

Gambar 5 Analisis spektrum pada masing-masing lintasan. 


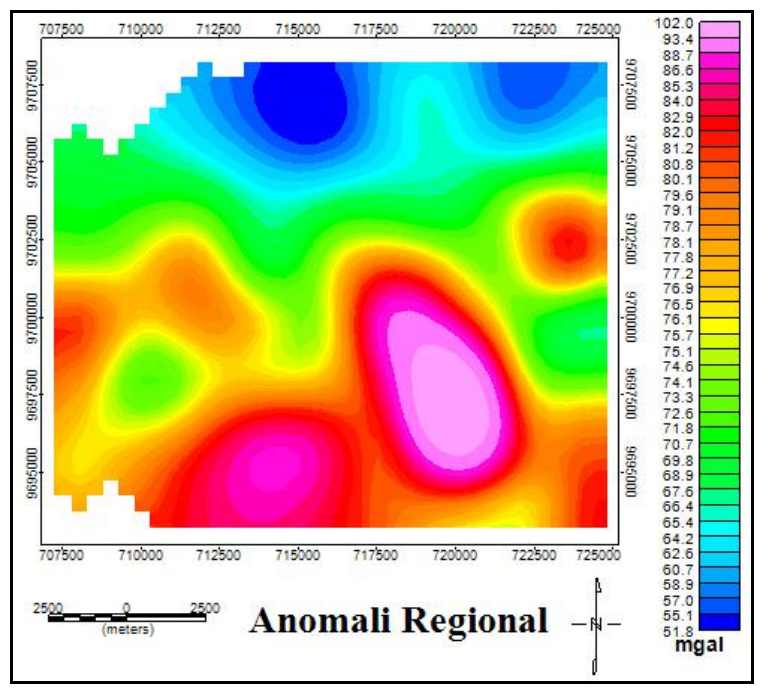

Gambar 6. Peta anomali gayaberat regional daerah Mamuju.

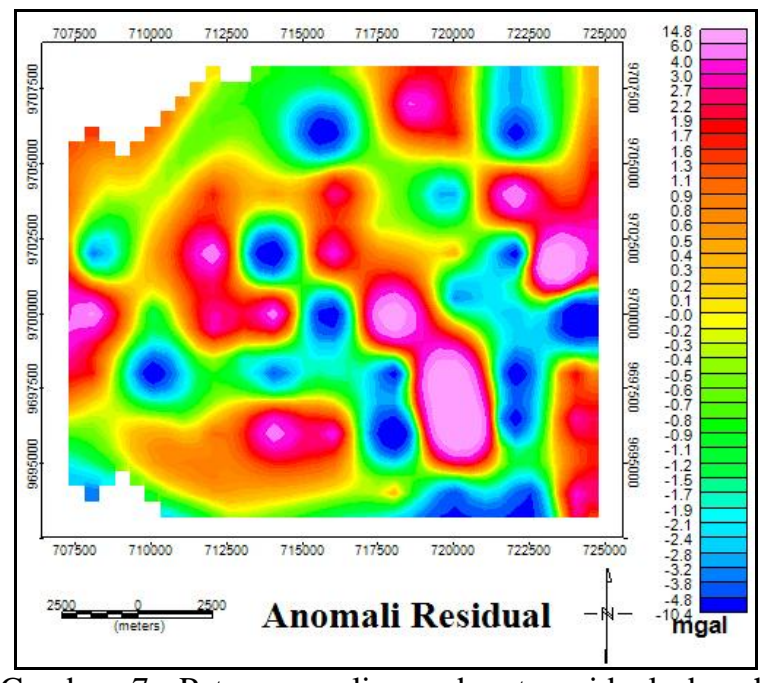

Gambar 7. Peta anomali gayaberat residual daerah Mamuju.

Secara umum geologi daerah penelitian tersusun atas kelompok batuan plutonik, sedimen tua, batuan gunung api, serta batuan sedimen muda (Gambar 8). Kelompok sedimen tua merupakan sedimen gunung api berupa batulempung dan batupasir berlapis. Batuan gunung api memiliki variasi yang sangat beragam, baik jenis maupun komposisi. Daerah penelitian termasuk ke dalam kelompok batuan gunung api Adang yang dibagi menjadi tujuh satuan batuan, yaitu: komplek Tapalang, Ampalas, Adang, Malunda, Karampuang, Sumare, dan Labuan
Rano. Batuan sedimen yang lebih muda didominasi oleh produk klastika gunung api dan batuan karbonat. Batuan sedimen ini dapat dibedakan menjadi beberapa satuan. Satuan tertua adalah satuan batugamping kristalin bagian atas yang terdiri dari batugamping terumbu yang telah mengalami kristalisasi dan sebagian telah terubah (terkersikkan) sehingga sebagian komponen batugamping telah terubah menjadi silika. Batuan ini diperkirakan memiliki umur yang hampir sama dengan batuan gunung api. Sedimen yang lebih muda adalah batuan konglomerat gunung api yang terbentuk di daerah ini dan merupakan hasil rombakan atau longsoran batuan gunung api yang bersifat grain supported [3].

Gambar 9 menunjukkan kontur anomali gayaberat residual dengan latar belakang peta geologi daerah penelitian. Urutan satuan kelompok batuan yang tercakup dalam pengukuran gayaberat dari umur muda ke tua adalah endapan aluvial, batugamping terumbu, konglomerat vulkanik, lava dome, batugamping kristalin, lava Adang, breksi Adang, lava Malunda dan breksi [3]. Berdasarkan peta penyebaran anomali gayaberat residual dapat dibagi lima daerah anomali yang bisa dinamakan zona A, B, C, $\mathrm{D}$ dan E. Zona anomali $\mathrm{A}, \mathrm{B}$, dan $\mathrm{C}$ yang berada di bagian tengah daerah penelitian membentuk suatu kontur tertutup yang terdapat pada kelompok batuan breksi Adang dan lava Adang. Terlihat jelas bahwa keterdapatan lava Adang cukup dekat dengan keberadaan zona-zona anomali gayaberat tersebut. Antara zona anomali A dan B kemungkinan ada suatu hubungan/asosiasi yang bisa dikontrol oleh keberadaan zona lemah (fracture), di dalam peta geologi digambarkan adanya kelurusan sungai. Zona anomali D terdapat pada satuan batuan breksi 
sedangkan zona anomali E terdapat pada lava Malunda. Keterdapatan batuan lava yang menumpang pada batuan vulkanik lainnya diperkirakan memiliki pengaruh sangat signifikan untuk membentuk anomali gayaberat residual positif. Respon anomali gayaberat positif dibentuk oleh objek bawah permukaan dengan densitas lebih besar dari lingkungannya. Lava Adang kemungkinan memiliki rapat massa lebih tinggi dibanding batuan vulkanik lainnya yang dianggap sebagai hostrock.

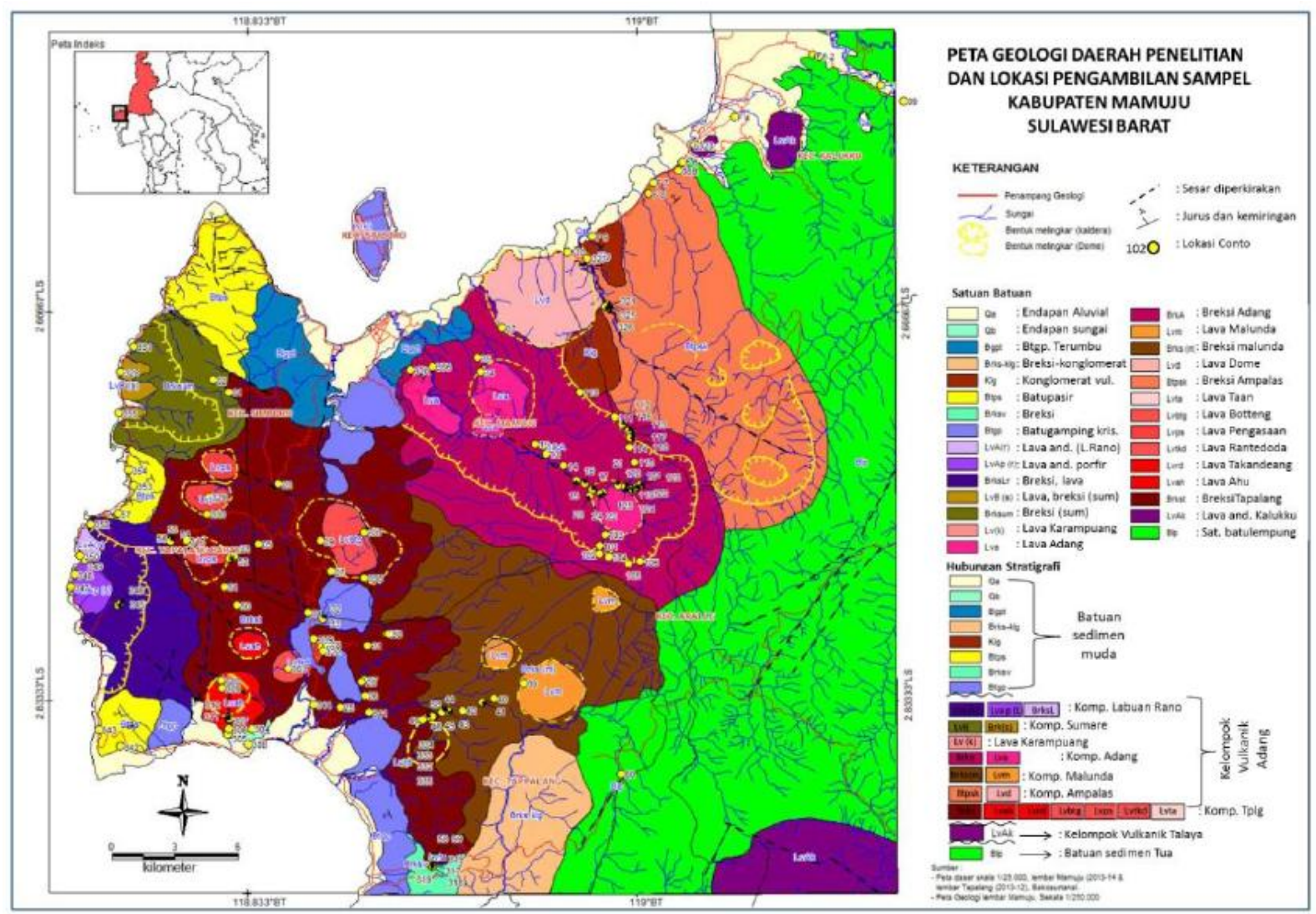

Gambar 8. Peta geologi daerah Mamuju dan sekitarnya [3].

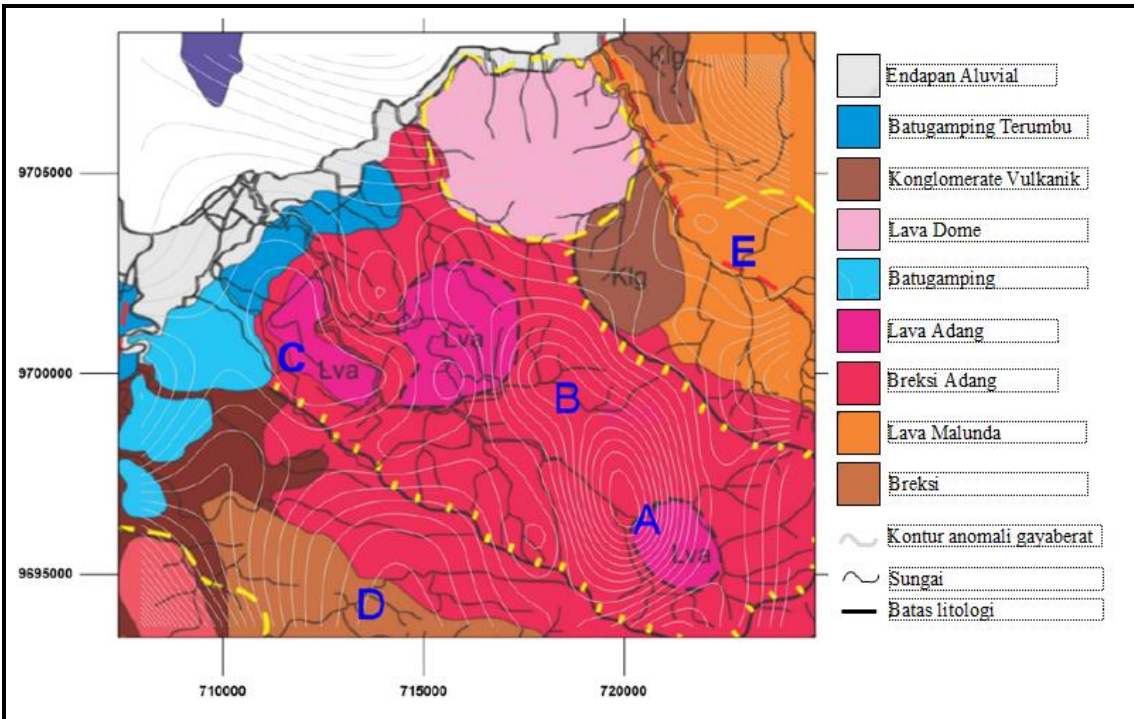

Gambar 9. Peta kontur anomali gayaberat residual dengan latar belakang peta geologi daerah penelitian 


\section{KESIMPULAN}

Nilai anomali Bouguer yang didapatkan di daerah Mamuju Sulawesi Barat adalah 46,0 mGal sampai dengan 115,7 mgal. Teknik Gauss filtering dalam proses pemisahan anomali regional dan residual bekerja pada harga bilangan gelombang sebesar 1,1736/m dan panjang gelombang sebesar $5.373 \mathrm{~m}$. Rentang nilai anomali regional yang diperoleh adalah 51,8 sampai $102 \mathrm{mGal}$ dengan kedalaman pengaruhnya sebesar 970,97 m. Sementara itu, anomali residual diperoleh sebesar -10,4 mGal sampai 14,8 mGal dengan kedalaman pengaruhnya 100,21 m. Terdapat lima zona anomali A, B, C, D, dan $\mathrm{E}$ dengan anomali gayaberat tertinggi berada di zona A dan B yang diperkirakan dipengaruhi oleh keberadaan lava Adang yang menumpang pada batuan vulkanik lainnya dengan penyebaran berarah relatif utara - selatan.

\section{UCAPAN TERIMA KASIH}

Ucapan terima kasih kami sampaikan kepada Kepala PTBGN-BATAN yang telah memberikan dukungan baik berupa arahan dan pendanaan atas terselenggaranya dan kelancaran penelitian gayaberat regional di daerah Mamuju.

\section{DAFTAR PUSTAKA}

[1] A. F. Soputan, Struktur Geologi Sulawesi. Bandung: Perpustakaan Sains Kebumian ITB, 2012.

[2] F. D. Indrastomo, I. G. Sukadana, A. Saepuloh, A. H. Harsolumakso, and D. Kamajati, "Interpretasi Volkanostratigrafi Daerah Mamuju Berdasarkan Analisis Citra Landsat-8," Eksplorium, vol. 36, no. 2, pp. 71-88, 2015.
[3] I. G. Sukadana, A. Harijoko, and L. D. Setijadji, "Tataan Tektonika Batuan Gunungapi di Komplek Adang, Kabupaten Mamuju, Provinsi Sulawesi Barat," Eksplorium, vol. 36, no. 1, pp. 31-44, 2015.

[4] I. G. Sukadana, F. D. Indrastomo, and H. Syaeful, "Geology and Radionuclide Ratio Mapping For Radioactive Mineral Exploration in Mamuju, West Sulawesi," in Prosiding Seminar Nasional Teknologi Energi Nuklir, 2015, pp. 140-147.

[5] D. Iskandar, Syarbaini, and Kusdiana, "Map of Environmental Gamma Dose Rate of Indonesia," PTKMR-BATAN, 2007.

[6] H. Syaeful, I. G. Sukadana, and A. Sumaryanto, "Radiometric Mapping for Naturally Occurring Radioactive Materials (NORM) Assessment in Mamuju, West Sulawesi," Atom Indones., vol. 40, no. 1, p. 35, May 2014.

[7] I. G. Sukadana, H. Syaeful, F. D. Indrastomo, K. S. Widana, and E. Rakhma, "Identification of Mineralization Type and Specific Radioactive Minerals in Mamuju, West Sulawesi," J. East China Univ. Technol., vol. 39, pp. 39-48, 2016.

[8] R. J. Blakely, Potential Theory in Gravity and Magnetic Applications. Cambridge University Press, 1995.

[9] R. D. Indriana, "Estimasi Ketebalan Sedimen dan Kedalam Diskontinuitas Mohorivicic Daerah Jawa Timur dengan Analisis Power Spectrum Data Anomali Gravitasi," Fis. Univ. Diponegoro, vol. 11, no. 2, 2008.

[10] Z. Afifa, "Implementasi Metode Gaussian Filter Untuk Penghapusan Noise Pada Citra Menggunakan GPU," UIN Maulana Malik Ibrahim Malang, 2016.

[11] B. Yuwono, "Image Smoothing Menggunakan Mean Filtering, Median Filtering, Modus Filtering dan Gaussian Filtering," Telemat. UPN Veteran, vol. 7, no. 1, 2010.

[12] I. P. Sari, "Studi Komparasi Metode Filtering Untuk Pemisahan Anomali Regional dan Residual Dari Data Anomali Bouguer," Universitas Indonesia Jakarta, 2012.

[13] J. M. Reynolds, An Introduction to Applied and Environmental Geophysics, Second. John Willey \& Sons, Ltd, UK, 1997.

[14] M. Sarkowi, Eksplorasi Gayaberat. Graha Ilmu Yogyakarta, 2014. 